\title{
Stress Coping Mechanisms adopted by Banking Sector Employees for Downsize the Stress: a Study
}

\author{
DR.R.Priya \\ Assistant Professor, Department of Management Studies, Thanthai Hans Roever College, Perambalur, Tamil \\ nadu, India.
}

\begin{abstract}
The study aims to identify the stress coping mechanisms adopted by both private and public sector banking employees for downsize the stress. The data collected from 400 bank employees of both private and public sector banking employees of Perambalur District, have been used to identify the stress coping mechanisms adopted by the respondents. The factor analysis has been applied for grouping of the variables. The findings indicate eight coping dimensions- Time management, Physical relaxation, Entertainment, Optimistic Approach, Adequate rest, Temporary Relaxation, Diversion and Decentralization. Further the results indicate that private and public sector banks significantly differ on coping dimensions.
\end{abstract}

Key Words: Stress- Coping mechanisms- Banking employees

\section{Introduction}

Coping is a concept that has been developed to reflect the various ways adopted by individuals to handle stress. The conceptualization of coping mechanisms used by the employees is crucial for effective management of stress which has been acknowledged as an important concern in organizational settings (Aziz, 2004; Dasgupta and Kumar, 2009; and Fernandes et al., 2009). Its importance for the management of stress cannot be undermined as it the important factor which can make the individual's ability to manage stress favourably. Basically, coping has been defined as "things that people do to avoid being harmed by life-strains" (Pearlin and Schooler, 1978) and "overt and covert behaviours that are taken to reduce or eliminate psychological distress or stressful conditions" (Fleishman, 1984). Of the many challenges individual face, coping with stress has assumed great importance (Pestonjee, 1992) due to the debilitating effects of stress on employees and organisations (Allison, 1997; Arnten et al., 2008; Karatepe and Uludag, 2008; and Garrosa et al., 2011).

With a view to comprehending coping, responses underlying coping have been examined by Moos and Billing (1982). However, Sharma (1988) found a paucity of meaningful research on coping strategies for dealing with stress in various different occupational groups. Specifically, there is a dearth of studies on coping strategies adopted by the banking employees who face very busy and highly demanding work days with many issues competing with their time. The study aims to develop an understanding of the stress coping mechanisms used by the banking employees, and to examine whether significant exists in the coping dimensions of private and public sector banks. First this article reviews the relevant literature and subsequently presents sampling framework and adopted research methodology. The analysed results are presented and discussed at the end of the article.

\section{Statement Of The Problem}

The banking sector is one among the important sectors of a nation and certainly this sector and its employees need to safeguard from the abnormal and unwanted stress. Because, their role is continuously as well as constantly required to a nation for its constant growth and development. Likewise the banking sector has to concentrate more on designing of suitable stress coping mechanisms for off-load the unwanted stress of their employees to ensure the better performance. So, the above said reasons are motivated the authors to concentrate on this issue to conduct a research. Hence many factors influence the stress among the employee's of both private and public banking sector to overcome from the stress the banking employee's are adopting many useful as well as innovative stress coping mechanisms. The researcher is basically indented to know their stress coping mechanisms and their strengths and weaknesses.

\section{Review Of Literature}

Stress coping mechanism is a kind of device or components used by the individuals to off-load or downsize the volume of stress in their life. All of us know that, an optimum amount of stress is compulsorily required to keep-up our performance. Otherwise if there is no amount of stress, ultimately we will be looking as an ideal. At the same time if there is an abnormal stress certainly it will spoil the performance of an individual and lead to stress. So, to overcome from the abnormal as well as unwanted stress an individual can identity and display his or her own stress coping mechanism based on his or her nature of job. The following literatures will 
describe the various types of stress coping mechanisms and their role to off-load the stress.

Oke and Patrick Dawson (2008) opined that, employee experience of stress reflects both individual characteristics as well as more collective qualities that are shaped by contextual factors. They have concluded that too much of emphasis is placed on individual-based program for managing stress and that more attention needs to be given to broader contextual issues in managing the conditions in which workplace stress is experienced. Purushothaman, et al (2012) proof that, the emotional intelligence competencies have positive and strong impact on reducing stress. It is decided that more than 80 percentage employees of banking sector experience stress on a daily basis and expect the management to support to reduce the volume of stress. It concludes that the highly emotional intelligence managers can control the level of stress among employees better and vice-versa. Catherine (2013) examined that, Emotional Intelligence (EI), perceived leadership style and job characteristics significantly and jointly predicted stress, in addition, those with high emotional intelligence reported lower stress experience compared with those with low level of emotional intelligence. This lies in the identification of the factors that are central to a person controlling his or her stress and suggesting strategies to promote the stress reduction process.

Arti Devi (2012) aimed to identify the coping strategies used for managing role stress at commercial banks. The results have indicated that the public and private sector commercial banks do not significantly differ on coping dimensions. Ajay kumar Singh and Nidhidewan (2006) have found that, there is no significant difference between both private and public banks for using coping mechanisms. An effort should be made to have a friendly climate with appropriate physical working condition. The relevance for the development of platforms to intensify communication throughout the workplace is essential which would not only reduce role ambiguity at work but also helps employees prioritize the tasks for better management of work leading to stress free environment and friendly organizational climate. Michie (2012) said that the training helps to prevent stress through becoming aware of the signs of stress. A wide variety of training courses may help in developing active coping techniques-for example, assertiveness, communications skills, time management, problem solving and effective management. Yahaya et.al (1996) concluded that, male and female, married and unmarried respondents were significantly different in their coping strategies.

\section{Research Methodology}

The study has been descriptive in nature. The study is based on both primary and secondary data. There are 10 public sector banks and 9 private sector banks in Perambalur district. The researcher has focused on all public sector banks and private sector banks of Perambalur district for the purpose of the study. A sample size of 400 respondents was randomly taken for this study. 5 point Likert scale was used for the collection of data. Statistical Package for Social Sciences (SPSS) was used to analyze and interpret the data.

\section{Factor Analytical Approach}

With a view to studying the coping strategies used by the employees of banks in the private and public sector, the responses of respondents have been examined with help of factor analysis. Initially, tests to check the adequacy of the data for the application of factor analysis were conducted. The value of the Kaiser- Meyer- Okin (KMO) measure of sampling adequacy statistic was found to be 0.669 , which is adequately large. Moreover, the correlation matrix reveals that there is enough correlation for the application of factor analysis. Besides, the Bartlett's test of sphericity value was found that to be 3094.46, which is also significant at 5 percent level.

Table 1 - Total Variance Explained - stress coping mechanisms

\begin{tabular}{|c|c|c|c|c|c|c|}
\hline Component & \multicolumn{3}{|c|}{ Initial Eigen values } & \multicolumn{3}{|c|}{ Rotation Sums of Squared Loadings } \\
\hline & Total & $\begin{array}{l}\% \text { of } \\
\text { Variance }\end{array}$ & $\begin{array}{l}\text { Cumulative } \\
\%\end{array}$ & Total & $\begin{array}{l}\% \text { of } \\
\text { Variance }\end{array}$ & $\begin{array}{l}\text { Cumulative } \\
\%\end{array}$ \\
\hline 1 & 4.418 & 16.992 & 16.992 & 3.203 & 12.321 & 12.321 \\
\hline 2 & 2.506 & 9.638 & 26.630 & 2.368 & 9.107 & 21.428 \\
\hline 3 & 2.270 & 8.732 & 35.361 & 2.118 & 8.148 & 29.575 \\
\hline 4 & 1.814 & 6.977 & 42.339 & 2.038 & 7.838 & 37.414 \\
\hline 5 & 1.658 & 6.378 & 48.717 & 1.890 & 7.269 & 44.683 \\
\hline 6 & 1.357 & 5.218 & 53.935 & 1.834 & 7.055 & 51.738 \\
\hline 7 & 1.195 & 4.597 & 58.532 & 1.555 & 5.982 & 57.720 \\
\hline 8 & 1.118 & 4.299 & 62.831 & 1.329 & 5.111 & 62.831 \\
\hline 9 & .962 & 3.700 & 66.530 & & & \\
\hline 10 & .942 & 3.623 & 70.154 & & & \\
\hline 11 & .819 & 3.150 & 73.304 & & & \\
\hline 12 & .707 & 2.718 & 76.022 & & & \\
\hline 13 & .696 & 2.677 & 78.699 & & & \\
\hline 14 & .665 & 2.557 & 81.256 & & & \\
\hline 15 & .627 & 2.410 & 83.666 & & & \\
\hline 16 & .598 & 2.301 & 85.967 & & & \\
\hline
\end{tabular}




\begin{tabular}{|l|l|l|l|l|l|l|}
\hline 17 & .520 & 2.000 & 87.967 & & & \\
\hline 18 & .496 & 1.908 & 89.875 & & & \\
\hline 19 & .447 & 1.720 & 91.596 & & & \\
\hline 20 & .387 & 1.490 & 93.085 & & & \\
\hline 21 & .365 & 1.404 & 94.489 & & & \\
\hline 22 & .348 & 1.339 & 95.828 & & & \\
\hline 23 & .326 & 1.255 & 97.083 & & & \\
\hline 24 & .296 & 1.138 & 98.221 & & & \\
\hline 25 & .272 & 1.045 & 99.265 & & & \\
\hline 26 & .191 & .735 & 100.000 & & & \\
\hline
\end{tabular}

Extraction Method: Principal Component Analysis.

From the above table, it is found that twenty six variables are reduced into eight predominant factors with individual variances $12.321,9.107,8.148,7.838,7.269,7.055,5.982$ and 5.111 and the total variance $62.831 \%$. This shows that the twenty six variables of stress coping mechanisms factors are reduced into eight predominant factors to represent their respective underlying variables. The following information clearly explains the variable loadings in each factor.

Table 2, Rotated Component Matrix

\begin{tabular}{|c|c|c|c|c|c|c|c|c|c|}
\hline \multirow[t]{2}{*}{ Dimensions } & \multirow[t]{2}{*}{ Coping Mechanisms } & \multicolumn{8}{|c|}{ Component } \\
\hline & & 1 & 2 & 3 & 4 & 5 & 6 & 7 & 8 \\
\hline \multirow{6}{*}{$\begin{array}{l}\text { Time } \\
\text { Management }\end{array}$} & Manage time. & .783 & & & & & & & \\
\hline & $\begin{array}{l}\text { Adequate role } \\
\text { Clarification }\end{array}$ & .732 & & & & & & & \\
\hline & Quit the job. & .685 & & & & & & & \\
\hline & $\begin{array}{l}\text { Set goals daily and } \\
\text { prioritize the work. }\end{array}$ & .624 & & & & & & & \\
\hline & $\begin{array}{l}\text { Prepare an action plan } \\
\text { for the work. }\end{array}$ & .622 & & & & & & & \\
\hline & Seek professional help & .575 & & & & & & & \\
\hline \multirow{3}{*}{$\begin{array}{l}\text { Physical } \\
\text { Relaxation }\end{array}$} & Engage physical exercises & & .814 & & & & & & \\
\hline & $\begin{array}{l}\text { Engage in a hobby like } \\
\text { reading, painting, etc. }\end{array}$ & & .800 & & & & & & \\
\hline & Indulge in meditation or yoga & & & & & & & & \\
\hline \multirow[t]{3}{*}{ Entertainment } & Leave the tension at work. & & & .768 & & & & & \\
\hline & Take Coffee, tea, etc. & & & .729 & & & & & \\
\hline & $\begin{array}{l}\text { Use entertainment sources } \\
\text { like TV, music. }\end{array}$ & & & .621 & & & & & \\
\hline \multirow{4}{*}{$\begin{array}{l}\text { Optimistic } \\
\text { Approach }\end{array}$} & Impart counseling & & & & .752 & & & & \\
\hline & $\begin{array}{l}\text { Try to look at things } \\
\text { differently. }\end{array}$ & & & & .557 & & & & \\
\hline & $\begin{array}{l}\text { Take planned break } \\
\text { from work }\end{array}$ & & & & .551 & & & & \\
\hline & Sleep more. & & & & -.476 & & & & \\
\hline \multirow[t]{3}{*}{$\begin{array}{l}\text { Adequate } \\
\text { Rest }\end{array}$} & $\begin{array}{l}\text { Grievance handling } \\
\text { Procedure }\end{array}$ & & & & & .777 & & & \\
\hline & Talk with friends/ family. & & & & & .772 & & & \\
\hline & Stress audit. & & & & & & & & \\
\hline \multirow{3}{*}{$\begin{array}{l}\text { Temporary } \\
\text { Relaxation }\end{array}$} & Smoke/ drink alcohol & & & & & & .798 & & \\
\hline & Day dream. & & & & & & .609 & & \\
\hline & Complaint. & & & & & & .448 & & \\
\hline \multirow[t]{3}{*}{ Diversion } & $\begin{array}{l}\text { Delegate responsibility } \\
\text { instead of carrying it alone }\end{array}$ & & & & & & & .645 & \\
\hline & Redesign jobs & & & & & & & .607 & \\
\hline & Write stress diary. & & & & & & & .479 & \\
\hline $\begin{array}{l}\text { Decentralizati } \\
\text { on }\end{array}$ & $\begin{array}{l}\text { Open channel of } \\
\text { communication }\end{array}$ & & & & & & & & -.706 \\
\hline
\end{tabular}

The above table depicts that the name factors with constituting variables and their respective factors loadings are summarized. The respective factors loadings represent the relationship between the original variable and its factor. The results, therefore, indicate that Time Management, Physical Relaxation, Entertainment, Optimistic Approach, Adequate rest, Temporary Relaxation, Diversion and Decentralization are the eight coping dimensions used by the banking employees.

A comparison of Stress Coping Mechanisms adopted by the Private and Public sector Banking employees.

An attempt has been made throw light on the significance differences in the coping strategies across private and public sector banks. The null hypothesis is: 
Ho: There is no significant differences in the coping mechanisms adopted by the employees of private and public sector banks.

The following table depicts that, a comparative profile of coping mechanisms as used by the employees of private and public sector banks. In addition, results of analysis shows that the of variance for sector differences.

Table 3- A comparison of coping mechanisms in Private and Public sector Banks

\begin{tabular}{|l|l|l|l|l|l|}
\hline \multirow{2}{*}{ Coping Mechanisms } & Public & \multicolumn{2}{l|}{ Private } & \multirow{2}{*}{-value } \\
\cline { 2 - 5 } & Mean & Std.Deviation & Mean & \multicolumn{1}{l|}{ Std.Deviation } & \\
\hline Time Management & 2.396 & 0.957 & 3.851 & 1.066 & -14.488 \\
\hline Physical Relaxation & 2.875 & 1.562 & 3.225 & 1.280 & -2.421 \\
\hline Entertainment & 3.703 & 1.321 & 3.576 & 1.277 & 1.012 \\
\hline Optimistic Approach & 3.307 & 1.357 & 3.207 & 1.336 & 0.665 \\
\hline Adequate Rest & 3.615 & 1.133 & 3.845 & 1.224 & -2.208 \\
\hline Temporary Relaxation & 2.343 & 1.309 & 2.213 & 1.241 & 1.06 \\
\hline Diversion & 2.716 & 1.051 & 2.98 & 1.303 & -1.999 \\
\hline Decentralization & 3.54 & 2.207 & 3.97 & 3.159 & -1.578 \\
\hline
\end{tabular}

The results brings into light that in order to compare the coping mechanisms of the private sector banks in comparison to those public sector banks on the usage of more Time management coping strategy. Strategies like Manage time, Adequate role clarification, quit the job, set the goals daily prioritize the work, prepare an action plan for the work and seek professional help. However, private sector employees have been found to rely engage physical exercise and engage in a hobby like reading, paining, etc to relax and burn the extra energy induced by stress in comparison to the public sector employees.

Conversely, employees of the public sector in comparison to that private sector use more of Entertainment coping strategy. One more dimensions of coping with stress, optimistic approach was also found to be applied more in public sector banks as compared to the private sector banks. Employees of the private sector banks in comparison to that public sector use more of adequate rest dimensions coping mechanisms. Temporary relaxation mainly used by public sector banking employees to compare the private sector banking employees. Conversely, Diversion coping, which reflects the employee tendency to combat stress by diverting the mind off the problem and focusing on other pursuits, delegate responsibility instead of carrying it alone, redesign jobs and write stress diary is more resorted to by the private sector employees as compared to their counterparts. On the same lines, decentralization coping mechanism also highly used by the private sector employees as compared to their counterparts. An important point to note is of the above relationships has been found to be statistically significant, which indicates some considerable differences in the uses of coping strategies to battle stress at public and private sector banks. So null hypothesis is rejected, and revealed that there is significant difference in coping dimensions of public and private sector banks.

\section{Conclusion}

From the responses to the coping mechanisms, it can be seen that employees of the public and private banks attempt to manage stress adopting and applying various coping mechanisms. Employees tend to cope by using Time management, Physical relaxation, Entertainment, Optimistic Approach, Adequate rest, Temporary Relaxation, Diversion, Decentralization. Also, it is revealed that, there is significant difference in coping dimensions of public and private sector banks. The results indicated that the private sector bank employees show keen interest in time management, temporary relaxation and decentralisation to reduce stress than public sector bank employees. The public sector bank employees adopt stress coping dimensions like adequate rest, entertainment and physical relaxation. Further it is found that, both the private and public sector employees disagree with adopting optimistic approach and diversion.

\section{Bibliography}

[1] Ajay Kumar Singh and Nidhi Dhawan. "A Study of Organizational Stress and Coping Mechanism in Public and Private Sector Banks", Research Paper Presentations on Contemporary Issues in the 13th Annual International Seminar at India Habitat Centre, New Delhi(2006).

[2] Allison D G. "Coping with Stress in the Principalship", Journal of Educational Administration 35(1) (1997): 39-55.

[3] Arnten A-C A, Janson B and Archer T. "Influece of Affective Personality Type and Gender upon Coping Behaviour, Mood and Stress", Individual Differences Research 6(3) (2008): 139-168.

[4] Arti Devi. “Coping Strategies by Bank employees to Manage Role Stress: A Study”, The IUP Journal of Management Research 11(4) (2012): 21-36.

[5] Aziz M. "Role stress among Women in the Indian Information Technology Sector", Women in Management Review 19(7) (2004): 356-363.

[6] Catherine Chovwen. "Occupational stress among bank employees in South East, Nigeria", Global Advanced Research Journal of Management and Business Studies 2(2) (2013): 114-119.

[7] Dasgupta H and Kumar S. "Roll Stress among Doctors Working in a Government Hospital in Shimla (India)", European Journal of Social sciences, 9(3) (2009): 356-370.

[8] Fernandas CFV, Kumar S and Mekoth N. "Gender Differences in Stress Among Bank Officers of Private and Public Sectors", The 
IUP Journal of Social Sciences 8(2) (2009): 63-69.

[9] Fleishman J A. "Personality Characteristics and Coping Patterns", Journal of Health and Social Behaviour 25(2) (1984): 229-244.

[10] Garrosa E, Moreno J B, Rodriguez M A and Rodriguez C R. "Role Stress and Personal Resources in Nurshing: A Cross- Sectional Study of Burnout and Engagement", International Journal of Nursing Studies 48(4) (2011): 479-489.

[11] Karatepe O M and Uludag O. "Role stress, Bornout and their Effects on Frontline Hotel Employees' Job Performance: Evidence from Northern Cyprus", International Journal of Tourism Research 10(2) (2008): 111-126.

[12] Michie S. "Causes and Management of Stress at Work", Occupational and Environmental Medicine 59(1) (2012): 67-72.

[13] Moos R H and Billings A G. "Conceptualising and Measurning Coping Resources and Processes", in L Goldberger and S Breznite (Eds.), Handbook of Stress: Theoritical and Clinical Aspects, Free Stress, New Yark (1982): 212-230.

[14] Oke A and Patrick Dawson. "Contextualizing workplace stress: the experience of bank employees in Nigeria", Australian and New Zealand Academy of Management 22nd Annual Conference, 2-5 December (2008).

[15] Pearlin L I and Schooler C. "The Structure of Coping", Journal of Health and Social Behaviour, 19(1) (1978): 2-21.

[16] Pestonjee D M. "Stress and Coping, the Indian Experience", Sage Publications (1992).

[17] Purushothaman K, Viswanathan M and Navaneetha kumar V. "An Analytical Study on Stress and Emotional Intelligence among Employees of Banking Sector in Bangalore City", European Journal of Social Sciences 29 (3) (2012): 413-420.

[18] Sharma S. "Stress and Anxiety", in J Pandey (Ed.), Psychology in India. The State-of the-Art, Personality and Mentel Processes, 1 (1988): 191-248. 